\title{
WELL INFORMED FARMERS AND CONSUMERS ARE POSITIVE ABOUT GM CROPS IN EUROPE AND AFRICA
}

\author{
Gheysen G.1,2, Maes J.1,3,4, Valcke M. ${ }^{3}$, Sanou E.I.R. ${ }^{1,5}$, \\ Speelman S. ${ }^{5}$, Heijde M.2,6 \\ 1 Department of Biotechnology, Faculty of Bioscience Engineering, Ghent University, \\ Belgium \\ 2 International Plant Biotechnology Outreach, VIB (Vlaams Instituut voor Biotechnologie), \\ Belgium \\ 3 Department of Educational Studies, Faculty of Psychology and Educational Sciences, \\ Ghent University, Belgium \\ 4 VIB (Vlaams Instituut voor Biotechnologie), Belgium \\ 5 Department of Agricultural Economics, Faculty of Bioscience Engineering, Ghent \\ University, Belgium \\ 6 Department of Plant Biotechnology and Bioinformatics, Ghent University, Belgium
}

Genetically modified (GM) crops are cultivated globally on more than 185 million hectares, but the use of GM crops in Europe and Africa is very limited. Politicians are reluctant to allow such crops because they fear negative public reaction. The political hostility in the EU towards GM crops also has a significant impact on how African policy makers form their opinions for accepting GM crops in their own countries. However, studies reveal that specific types of GM food are welcomed by consumers and that few Europeans avoid GM labels when buying food. Similarly, African farmers and consumers are generally positive about GM crops. Policy makers should take these results into account when a decision needs to be made on whether or not to allow GM crop cultivation in their country.

KEY WORDS: ACCEPTANCE, AFRICA, CONSUMERS, EUROPE, FARMERS, GM CROPS

\section{Introduction}

Genetically modified (GM) crops have been rapidly adopted worldwide, but Europe and Africa are striking exceptions. In the European Union (EU), crops obtained by genetic engineering, whether transgenic (transformed with genes from unrelated organisms) or gene edited (developed by changing only one or few nucleotides on a specific site in the DNA) are the subject of intense political debate. As a result of this polarised situation, several GM crops that have been considered safe by the European Food safety Authority (EFSA), have not received approval for cultivation in the EU. Currently cultivation of only one GM crop, an insect resistant maize, is permitted in the EU, and in 2017 it was only grown in Spain and Portugal (ISAAA, 2017). This EU restraint is often rationalised by claiming that the politicians' voting behaviour merely reflects public opinion. Surveys 
such as the Eurobarometer (e.g. Gaskell et al., 2006; 2010) are brought up to back the view that "EU consumers do not want GM crops", but this statement lacks nuance. A recent meta-survey analysing data from more than 200,000 respondents worldwide (Hess et al., 20I6) found that EU consumers in general are no more adverse to GM food than other consumers.

Certainly, when nearly 27,000 consumers from the 27 EU countries were asked this general question: “do you support GM food?”, $59 \%$ tended to disagree (Gaskell et al., 2010). However, many studies indicate that the context and the wording of questions influence the outcome, that specific examples of GM food are welcomed by consumers and that few Europeans avoid GM labels when buying food.

\section{EU consumers support specific GM applications}

Already in the Eurobarometer itself, distinctions can be found (Gaskell et al., 20I0). For example, disease resistant cisgenic apples can be obtained by genetic engineering with a gene from wild apples that provides mildew and scab resistance, reducing the need for fungicides. To the question whether they agree that these cisgenic apples are useful, $63 \%$ of the EU citizens replied positively. In 24 of the countries surveyed, an absolute majority of the respondents supports these cisgenic apples. Evidently there are major differences between countries with a high level of support ( $76 \%$ in Cyprus) versus a low level of support (35\% in Luxembourg).

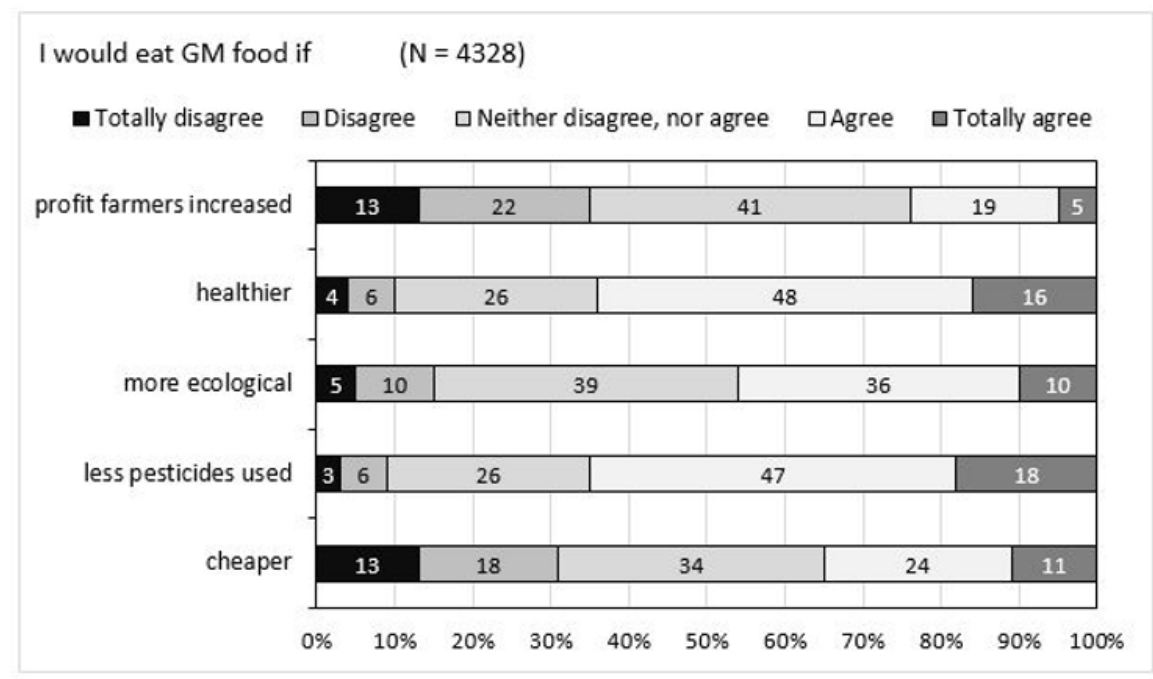

Figure 1: Example from consumer survey Flanders 2013.

The graph shows the percentage of people $(\mathrm{N}=4328)$ choosing one of 5 possible answers to the different questions starting with "I would eat GM food if..." 
Consumers from Spain and Portugal, where GM maize is cultivated, are more supportive of GM crops than consumers from countries that have a long tradition of voting against any GM crop (such as Austria, France and Germany). It is difficult to know whether the politicians adjust their views according to their voters or whether consumers are being influenced by the political climate which supports or criticizes GM crops. Nonetheless, it can be concluded that when the benefits of GM crops are communicated or experienced, support appears to be higher.

In 2013, a survey was performed to analyse the knowledge and attitudes of Flemish citizens regarding GM crops, interviewing 4328 persons, stratified over 5 age categories, 3 education levels and both genders. The survey revealed that consumers support GM applications if these crops are better for their health or the environment, with $65 \%$ of the respondents claiming they would eat GM food if less pesticides were used, with only 9\% not willing to do so (Figure I).

These results are very much in line with EU-data from Gaskell et al. (2006): 56\% of Europeans would buy GM foods if the foods are healthier, $5 \mathrm{I} \%$ if they lead to less pesticide residues and 49\% if they are more environment-friendly. Fewer Flemish people considered the benefit to the farmers as relevant, and the same was true for food prices. Most of the Flemish consumers are not related to farmers (only ca. 24,000 enterprises in agri- and horticulture on a population of more than $6 \mathrm{M}$ people (lv.vlaanderen.be/nl/voorlichtinginfo/feiten-cijfers/landbouwcijfers), explaining why they are less concerned about farmers' income than they are about their own health. With regard to food price, consumers in western countries sometimes perceive cheaper food as inferior, which may explain why fewer see this as positive compared to a health benefit.

\section{EU consumers buy GM food when available}

Questionnaires are not the best means of forming an accurate picture of whether people accept and purchase GM food (Dessaint \& Varbanova, 2013). People can be cautious when confronted with hypothetical questions, or they give an answer that they see as ideal. When buying food in an everyday situation, other factors come into play such as appeal and the price of the food. Therefore, studies on consumer choices in shops or in markets are a better indicator of real consumer behaviour.

For example, in Switzerland in 2008, Swiss consumers were offered three different types of cornbread at five market stands reaching more than 3000 customers (Aerni et al., 20II). The breads were made with corn that was either GM, organic or conventionally grown and they were clearly separated and labeled. Despite the general negative attitude towards GMO in Switzerland, about one quarter of the 3275 customers purchased GM bread. The percentage differed between market location and dropped only slightly (to $20 \%$ ) if the GM bread was more expensive than conventional bread. Another much smaller scale experiment in a German city showed that "GM" bread and "GM" French fries offered at a reduced price were bought four and 20 times respectively more than the conventional equivalents (Desaint \& Varbanova, 20I3). Knight et al. (2007) reported a market 
share of on average $2 \mathrm{I} \%$ for "GM fruit" being sold at roadside fruit stalls in 6 countries (five of which were in Europe), when this was the same price as the conventional and organic fruit. In most countries, this increased to 30-40\% when the GM fruit was offered at a $15 \%$ discount price and the organic at a $15 \%$ premium price.

Data on how EU consumers behave in supermarkets when confronted with GM food are limited because few GM products are available (basically some salad oils and derived products such as margarine or mayonnaise) and even then only in some EU-countries. In focus group discussions of the Consumer choice project (Moses, 2008; Framework 6 program) people wanted food to be labeled if GM. However, the same study found that nearly half of the consumers ( $48 \%$ ) that bought GM (confirmed by barcode scans) claimed not to buy GM-labeled food, indicating they had not read the labels in any detail. The conclusion of this EU-study was that most consumers do not actively avoid GM foods because they are not really concerned about it. In a special Eurobarometer survey on possible risks linked to food (TNS Opinion and social), $\mathrm{I} 6 \%$ of the respondents were worried about food poisoning, I4\% about pesticides and only $8 \%$ mentioned GMOs as a potential risk.

\section{Why do food companies and retailers avoid GM if most EU-consumers are not particularly concerned about it?}

The majority of soybeans used in European food and feed is imported and more than $75 \%$ of the global soybean production is GM. The GM figure is as high as $94-100 \%$ in the top 3 countries exporting soybeans to the EU (Brazil, USA and Argentina) (ISAAA, 20I7). Consequently, the majority of commercial feed manufactured in Europe contains GM ingredients and is labeled as such. However, very few food products containing GM soybean can be found on the supermarket shelves. The main reason for this is that retailers are afraid of negative publicity from environmental NGOs that intimidate them into removing GM labeled products (Lucht, 20I5). This was especially the case during the period when EU labeling regulations were implemented. Although the aim of the regulations was to provide a choice (GM or not) to the EU consumer, the result was in effect no choice.

For similar reasons, many political parties refrain from taking a pro-GM stance. The neutral to weak attitudes of most European citizens in the GM debate do not influence political parties, but the noisy minority that protests against GM does have an impact (Aerni, 2013). Political parties do not go against the anti-biotech activists as they do not want to risk losing face or their reputation.

\section{The EU propagates its anti-GM policy to Africa}

European farmers do not need GM crops to achieve high yields, although insect and disease resistant GM crops could reduce pesticide use. The number of farmers in Europe is also small, representing relatively few votes and therefore having little influence on political decisions. However, European politicians and NGOs that oppose GMOs are similarly very active at disseminating their ideas to stop the use of this technology in Africa as well, 
where agricultural innovation is a necessity for food security. An example of such European pressure was the report by the Members of the European Parliament and adopted by that Parliament in 2016 (EP resolution, June 7,2016 ) that calls for not supporting the use of GM crops in Africa.

Close to $70 \%$ of the African population is involved in agriculture mainly as smallholder farmers. African agriculture is not highly productive compared to the other continents and would certainly benefit from improved germplasms harboring for example insect, disease and drought resistance. The few African countries that currently grow GM crops (South Africa and Sudan), or have done it in the past (Burkina Faso) can testify to this (e.g. Sanou et al., 2018). Field trials with GM crops in other countries such as Kenya, Tanzania and Uganda demonstrate that higher yields can be obtained while reducing environmental pressure from pesticide applications (ISAAA, 20I7).

Kenya has a long-standing expertise in agricultural biotechnology with programmes beginning at the University of Nairobi and Kenya Agricultural Research Institute (KARI) as early as the 8o's and Jomo Kenyatta University of Agriculture and Technology (JKUAT) in the 90's (biosafetykenya.wordpress.com/2015/09/25/10-facts-on-biotechnology-inkenya/). Kenyan GM field trials started in 2004 and have continued since, but till now not a single GM crop has been approved for commercialization (ISAAA, 2017). Furthermore, in November 2012 Kenya imposed a ban on GMO crop imports based on a publication of Séralini et al. (2012) that stated that eating GMOs causes cancer. The experimental design and the conclusions of that paper were heavily criticized and the paper was retracted, but the damage had been done.

After more than 20 years in which GMOs have been grown, used as feed for our livestock and as food for people in many countries, and subject to hundreds of scientific studies, there is no evidence that approved GMOs have brought any new risks to either human health or the environment (Snell et al. 20I2; De Francesco, 20I3; Nicolia et al., 20I3; Klumper and Qaim, 2014).

This is also the official view of science academies and medical associations all over the world (e.g. National Academies of Sciences, Engineering, and Medicine, 20I6). In contrast, international NGOs headquartered in Europe spread a very different message that leads many African countries to hesitate on the question. Friends of the Earth International states on their website that "Genetically modified crops bring unnecessary risks to both humans and nature." Greenpeace International is well known for its anti-GMO actions such as destroying GM field trials. ActionAid-Uganda communicated on local radio that GM foods cause cancer and infertility (Karembu, 2017). The UK-based organisation later apologized, but the broadcast had already resulted in a rise of anti-GMO activism, causing further delay in the approval of the Uganda National Biosafety bill needed for GM crop cultivation .

Misrepresentation of the EU policy for GMO imports has further aggravated the indecision on GM crop cultivation in Africa. The EU has approved more than 75 GMO events and combinations thereof for import and use in food and feed (europa.eu/rapid/pressrelease_IP-I5-4843_en.htm). Food exports from the Republic of South-Africa to Europe 
continue to grow, while this African country grows more than 2.5 million ha of GM maize and soybean (ec.europa.eu/agriculture/sites/agriculture/files/trade-analysis/statistics/outside-eu/countries/agrifood-south-africa_en.pdf). Nevertheless, African governments are sometimes misinformed that Europe will reject food imports if they start cultivating GM crops (Paarlberg, 20I0; Karembu, 20I7).

\section{African farmers and consumers appreciate the benefits of GM crops}

In contrast to the often negative publicity in Africa on GM crops, and the indecision of African governments, there is enthusiasm among African scientists, for instance Kenya, Nigeria and Uganda develop solutions for problems in local crops using genetic engineering (ISAAA, 2017). In addition, many surveys indicate that African consumers are willing to accept GM food. For example, a 20II survey of 42I households in Uganda revealed that $92 \%$ of them would buy a GM banana if it was more nutritious (Kikulwe et al., 20II). Interestingly, scientists from the Ugandan National Agricultural Organisation are currently testing GM bananas with a higher pro-vitamin A content (Paul et al. 2018). In the frame of the Insect Resistant Maize for Africa (IRMA) project, Kimenju et al. (20II) performed a survey in Kenya involving over 800 consumers (604 in Nairobi and 200 from rural areas). Most consumers were willing to purchase GM maize meal at the same price as the conventional crop, although the acceptance level was clearly lower among urban consumers (58\%) than among rural consumers (89\%). More recently in Tanzania, Nyinondi et al. (2017) revealed 22 out of 24 journalists in their survey were positive about GM crops, but only $66.3 \%$ (II6 of I75) of the farmers. Tanzanian farmers did not have the experience of GM cultivation as this is not allowed in their country.

It is therefore interesting to explore the attitude of farmers in Burkina Faso where GM cotton, resistant to the cotton bollworm (Bt), was cultivated for six years starting in 2008. In 2015-20I6, the Burkina Faso cotton industry together with the government decided to stop the distribution of GM cotton seeds to farmers because they were not satisfied with the fiber length of the GM cotton cultivars (Sanou et al., 2018). During this 20152016 period, data were collected from 3234 cotton farmers to test their knowledge and opinion about Bt cotton. All respondents were positive about the reduction in insecticide treatments when using Bt cotton and the majority (89\%) of the farmers disagreed with the decision to suspend Bt cotton cultivation until better fiber varieties are available. At the same time, I50 farmers (half of them growing GM cotton) were also queried about their interest in growing bio-fortified sorghum that was genetically engineered to contain more pro-vitamin A, iron and zinc (Obi et al., 20I8). On average $73 \%$ of the farmers were willing to cultivate the GM bio-fortified sorghum, with a higher commitment from the farmers who already had experience with GM cotton.

\section{Conclusion}

Both Europe and Africa have limited experience with cultivation of GM crops, mainly due to political constraints. However, research and development on GM crops with consumer benefits or for a more sustainable agriculture are continuing. Analysis of surveys 
that examine the willingness of farmers to grow GM crops and of consumers to buy their produce demonstrates that if these crops are available, they are welcomed. Policymakers, food companies and retailers should pay attention to these results instead of teaming up with the small group of anti-biotech activists.

\section{Acknowledgments}

The authors acknowledge FWO (ERAfrica) and Ghent University for funding research into GMO perception of farmers and consumers. They are grateful to Vanessa De Bauw for making figure $\mathrm{I}$.

\section{References}

Aerni, P., Scholderer, J., Ermen, D. (20II). How would Swiss consumers decide if they had freedom of choice? Evidence from a field study with organic, conventional and GM corn bread. Food Policy $36(6): 830-838$.

Aerni, P. (2013). Resistance to agricultural biotechnology: The importance of distinguishing between weak and strong public attitudes. Biotechnology Journal, 8 (IO): II29-II32.

africenter.isaaa.org/wp-content/uploads/20I5/o8/Kenya-Topio-Facts-A4-FINAL-Web-Version.pdf

De Francesco (2013). How safe does transgenic food need to be? Nat. Biotechnol. 31:794-802.

ec.europa.eu/agriculture/sites/agriculture/files/trade-analysis/statistics/outside-eu/countries/agrifoodsouth-africa_en.pdf

European Parliament resolution June 7 20I6: http://www.europarl.europa.eu/sides/getDoc. do?pubRef=-//EP//TEXT+TA+P8-TA-20I6-0247+o+DOC+XML+Vo//EN

Desaint N., Varbanova M. (2013) The use and value of polling to determine public opinion on GMOs in Europe: limitations and ways forward. GM Crops Food 4 (3): $183-194$.

Gaskell G., Stares S., Allansdottir A., Allum N., Corchero C., Fischleret C., et al. (2006) Europeans and biotechnology in 2005: patterns and trends. Special Eurobarometer 2006; 244b:I0

Gaskell G., Stares S., Allansdottir A., Allum N., Castro P., Esmer Y., Fischler C., Jackson J., Kronberger N., Hampel J., Mejlgaard N., Quintanilha A., Rammer A., Revuelta G., Stoneman P., Torgersen H., Wagner W (2010). Europeans and Biotechnology in 2oro Winds of change? Eurobarometer 20I0; 34I.

Hess S., Lagerkvist C.J., Redekop W., Pakseresht A. (20I6) Consumers' evaluation of biotechnologically modified food products: new evidence from a meta-survey

European review of agricultural economics 43, 703-736 DOI: I0.I093/erae/jbwoII

ISAAA. 2017. Global Status of Commercialized Biotech/GM Crops in 20I7: Biotech Crop Adoption Surges as Economic Benefits Accumulate in 22 Years. ISAAA Brief No. 53. ISAAA: Ithaca, NY.

Karembu M (2017). How European-Based NGOs Block Crop Biotechnology Adoption In Africa. geneticliteracyproject.org/wp-content/uploads/2017/03/Karembu_edits_v5.pdf

Kikulwe E.M., Wesseler J., Falck-Zepeda J. (20II) Attitudes, perceptions, and trust. Insights from a consumer survey regarding genetically modified banana in Uganda. Appetite 57 (2): 40I-4I3. doi:Io.Ior6/j.appet.20II.o6.0oI

Kimenju S.C., De Groote H., Bett C., Wanyama J. (20II). Farmers, Consumers and Gatekeepers and Their Attitudes towards Biotechnology. African Journal of Biotechnology ro (23): 4767-76.

Klümper W., Qaim M. (20I4). A meta-analysis of the impacts of genetically modified crops. PLoS One, 9 (II): eiri629.

Knight J.G., Mather D.W., Holdsworth D.K., Ermen D.F. (2007) Acceptance of GM food - an experiment in six countries. Nature Biotechnology 25 (5): 507-508. DOI: I0.1038/nbto507-507 
Lucht J.M. (2015). Public acceptance of plant biotechnology and GM crops. Viruses, 7(8): 4254-428I.

Moses V. (2008). Do European consumers buy GM foods? European Commission: Framework 6. 2008. Available from: http://www.kcl.ac.uk/consumerchoice

National Academies of Sciences, Engineering, and Medicine (2016). Genetically Engineered Crops: Experiences and Prospects. Washington, DC: The National Academies Press. doi: 10.17226/23395

Nicolia A., Manzo A., Veronesi F., Rosellini D. (2013). An overview of the last ro years of genetically engineered crop safety research. Crit. Rev. Biotechnol. 855I: I-I2. doi:10.3109/07388551.2013.82 3595 .

Nyinondi P.S., Dulle F.W., Nawe J. (2017). Perception of agricultural biotechnology among farmers, journalists and scientists in Tanzania. University of Dar es Salaam Library Journal no. 2005: IO6-I2O.

Obi C., Sanou E.I.R., Tur-Cardona J., Bartolini F., Gheysen G., Speelman S. (2018). Farmers' valuation of transgenic biofortified sorghum for nutritional improvement in Burkina Faso: A latent class approach. June 2018, Food Policy. doi.org/ro.1016/j.foodpol.2018.06.006

Paarlberg R. (2010) GMO foods and crops: Africa's choice. New Biotechnology 27 (5):609-613.

Paul J.-Y., Harding R., Tushemereirwe W., Dale J. (2018). Banana 2I: From Gene Discovery to Deregulated Golden Bananas. Frontiers in Plant Science 9: 558.

Sanou E.I.R., Gheysen G., Koulibaly B., Roelofs C., Speelman S. (2018). Farmers' knowledge and opinions towards Bollgard II((R)) implementation in cotton production in western Burkina Faso. New Biotechnology 42:33-4I.

Snell C., Bernheim A., Berge J.B., Kuntz M., Pascal G., Paris A., Ricroch A.E. (2012). Assessment of the health impact of GM plant diets in long-term and multigenerational animal feeding trials: A literature review. Food Chem. Toxicol. 50: II34-II48.

Séralini G.-E., Clair E., Mesnage R., Gress S., Defarge N., Malatesta M., Hennequin D., de Vendômois J.S. (20I2) RETRACTED: Long term toxicity of a Roundup herbicide and a Roundup-tolerant genetically modified maize. Food and Chemical Toxicology 50 (II): 422I-423I.

TNS Opinion and Social. Risk issue. Special Eurobarometer 2006; 238/Wave 64.I. 